\title{
MULTIVARIATE ANALYSIS OF WEEDS OF CHICKPEA, MUSTARD AND WHEAT CROP FIELDS OF TEHSIL ISAKHEL, DISTRICT MIANWALI (PUNJAB), PAKISTAN
}

\author{
Gulshan Riaz ${ }^{1}$, Zaheer-ud-din Khan ${ }^{1}$, Muhammad Umer Farooq Awan ${ }^{1}$, Andleeb \\ Anwar Sardar ${ }^{1}$, Muhammad Tayyab ${ }^{1}$, Sarah Maryam Malik and Sohaib Muhammad ${ }^{1}$ \\ DOI: https://doi.org/10.28941/pjwsr.v27i2.924
}

\begin{abstract}
Multivariate analysis through Two Way Indicator Species Analysis (TWINSPAN) was conducted to study the phytosociological attributes of weeds of some selected crop fields of chickpea, mustard and wheat of Tehsil Isa Khel, District Mianwali, Punjab. Forty one (41) weed species were collected from the study area belonging to twenty one (21) different families. Twenty four weed species found in chickpea, twenty five in mustard and twenty nine in wheat crop fields. Sixteen weed species were common in three crops. Family Poaceae and Astraceae had maximum weed species i.e. 7 and 6 species respectively followed by Euphorbiaceae, Fabaceae, Chenopodiaceae, Papaveraceae, Zygophyllaceae and so on. Asphodelus tenuifolius, Medicago monantha and Carthamus oxyacantha are frequently occurring weeds relative to others. Two-Way Indicator Species Analysis (TWINSPAN) was performed on the percentage cover basis which divided the weed species into groups, sub groups, associations and sub associations.
\end{abstract}

\section{Keywords: Multivariate Analysis, TWINSPAN, Weeds, Tehsil Isa Khel (Punjab)}

Citation: Riaz, G., Z. Khan, M.U.F. Awan, A.A. Sardar, M. Tayyab, S.M. Malik and S. Muhammad. 2021. Multivariate Analysis of Weeds Of Chickpea, Mustard And Wheat Crop Fields Of Tehsil Isakhel, District Mianwali (Punjab), Pakistan. Pak. J. Weed Sci. Res., 27 (2):153-162.

${ }^{1}$ Department of Botany, GC University, Lahore (54000)

Corresponding author email: dr.sohaibmuhammad@gcu.edu.pk 


\section{INTRODUCTION}

Weeds grow rapidly, spread faster and reproduce in great numbers due to their large number of seeds. They potentially drained the energy of ecosystem by damaging the crop's yield qualitatively and quantitatively by utilizing the source of water, sunlight, space and nutrients (Padal et al., 2013). These weeds may be annual, biennial and perennials, create hindrance in the agriculture practices like harvesting, ploughing, seed purification and provides shelter to harmful organisms (Nagaraju et al., 2014; Anderson, 1996). Weeds are found dynamic in their distribution pattern in different agroecological zones and their ecological attributes vary from area to area under different climatic conditions. So, over the years, much attention has been given to the phytosociological analysis of the weeds and now a days the preliminary ecological data is being used to conduct the multivariate analysis of weed species in their respective crops to address the distribution of weeds in more appropriate and accurate manner. So, it is necessary to conduct such studies to determine the weed communities or their distribution by identification and composition of weeds with respect to environmental variables (Hussain et al., 2015; Zeb et al., 2016). For this purpose various workers carried out research work in various parts of Pakistan and abroad as well, which are cited in following lines.

Waheed et al. (2009) found 37 weed plant species belonged to 17 different families in wheat fields of Distric Rahim Yar Khan. The major families were Poaceae, Asteraceae, Chenopodiaceae and Fabaceae. Phalaris minor and Melilotus indicus were frequently occurring weed species in wheat fields. Marwat et al. (2013) surveyed the wheat fields in Dera Ismail Khan and found 32 weed species which belonged to 15 different families. The weeds Rumex dentatus, Chenopodium album and Phalaris minor had highest relative density. Nagaraju et al. (2014) studied the phytosociology of weeds of sugarcane fields of Visakhaptnum, District Andhra Pradesh by selecting 100 fields and found the density, frequency, abundance and IVI of weeds. Total 88 weeds were collected belonged to 16 monocot and 72 dicot families.

Ullah et al. (2015) collected 46 weed species which belonged to 22 families in maize fields. Family Poaceae was found dominant followed by Family Amaranthaceae, Asteraceae, Lamiaceae, Cyperaceae and Solanaceae. Iqbal et al. (2017) studied phytosociological attributes of wheat fields and reported 132 weed species, out of which five major weed communities were reported. Navagana et al. (2017) collected 55 weeds from Visakhapatnam district, Andhra Pradesh, India. These weeds were belonged to 45 different genera and 21 families. Samreen et al. (2018) determined the qualitative characteristics of the weeds of Dera Ismail Khan in terms of leaf form and life form in which twenty seven weed species were reported, distributed among fifteen different plant families. Fazal et al. (2019) reported 23 weed species from maize, mungbean and potato fields of Kalash Valley, Chitral (Pakistan). Among all the species, Digitaria sanguinalis was found dominant in all the three crops. Hussain et al. (2020) conducted floristic and phytosociological studies and recorded 56 weed plant species belonged to 23 families.

By considering the importance of the weeds in crop fields and their diverse ecological distribution, present research work was designed to investigate the distribution of the weeds in chickpea, mustard and wheat crop fields of Tehsil Isa Khel, district Mianwali (Punjab).

\section{Study Area}

The present study area i.e. Tehsil Isa Khel, District Mianwali is located about 85 kilometers from Mianwali at an elevation of $198 \mathrm{~m}$ from sea level and situated at the latitude of $32^{\circ} 40^{\prime} 17.39^{\prime \prime}$ North and at longitude of $71^{\circ} 16^{\prime} 31.20^{\prime \prime}$ East. The district Mianwali is bounded on the north by district of Khyber Pakhtunkhwa (KPK) and Attock district of Punjab, on the east by Kohat districts, on the south by Bhakkar district of Punjab and on the west by Lakki Marwat, Karak and Dera Ismail Khan District of KPK again. Boundaries of Isa Khel are joined with the Indus and Kuram Rivers. Important crops of Isakhel 
are Wheat (Triticum aestivum), Mustard (Brassica compestris), rice (Oryza sativa), Chickpea (Cicer arietinum), Sugarcane
(Saccharum officinarum) and maize (Zea mays).

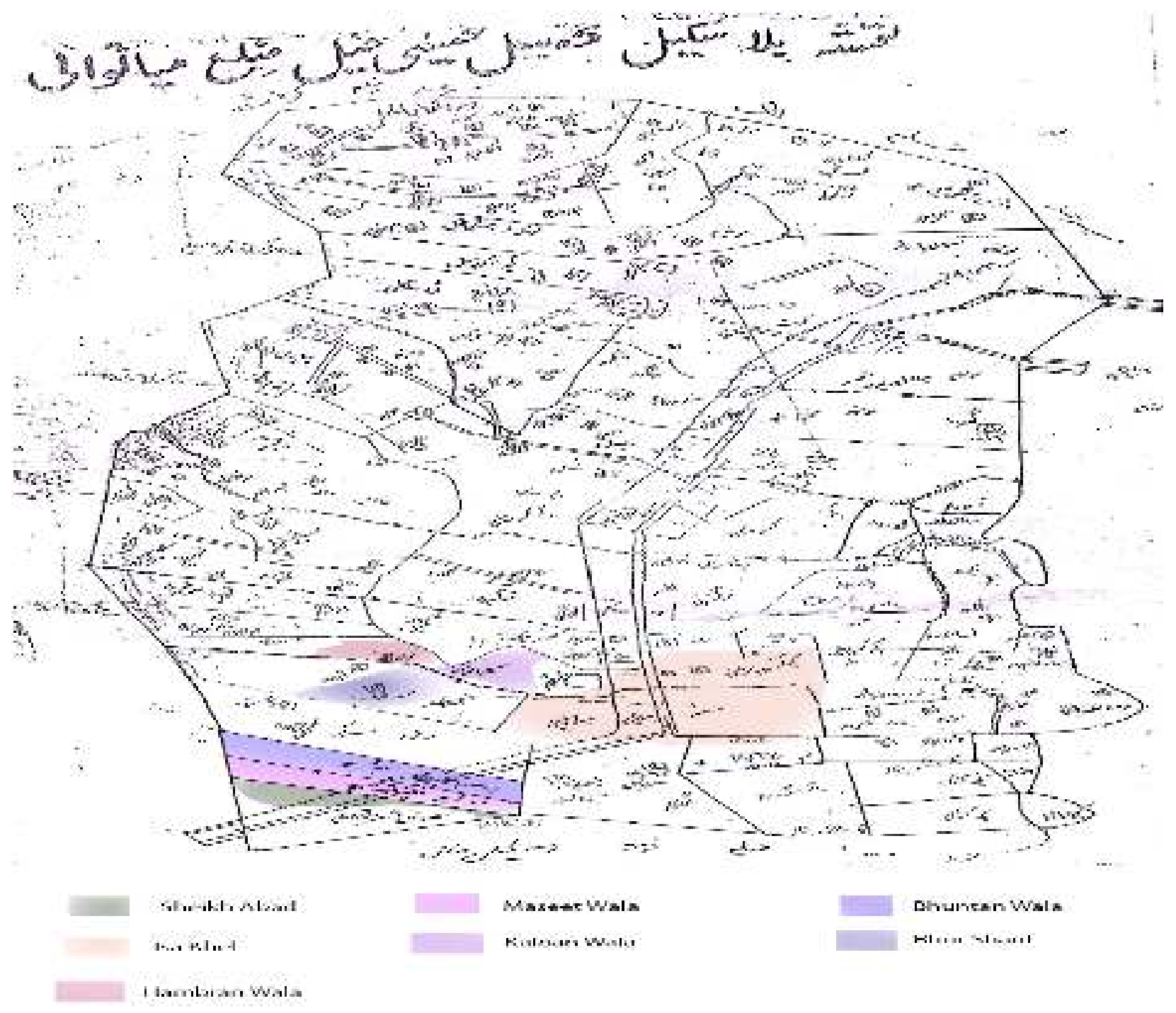

Figure 1: Map of Tehsil Isa Khel (Mianwali) with selected villages of crop fields

\section{Materials and Methods}

The present research work was undertaken to study the phytosociology of weeds of Chickpea, Mustard and Wheat crop fields of Tehsil Isa Khel, District Mianwali. Total five villages were selected for each crop and three sites were selected in each village. The selected villages were Sheikh Abad, Maseet Wala, Bhuttan Wala, Isa Khel, Kaloan Wala, Bhor Sharif and Hambran Wala as shown in Figure 1. Quadrat of $1 \mathrm{~m}^{2}$ was used randomly for sampling after Clements (1906). Percentage frequency, density and percentage cover was calculated after McIntosh (1962), Curtis and McIntosh (1950) and Daubenmire (1959) respectively in order to calculate the Importance Value Index (IVI) (Risser and Rice, 1971) of the weed species. Moreover, multivariate analysis was determined on the basis of percentage \% 
Cover to determine the groups, sub groups and associations of these three crops by using the PC-ORD (V-6.22) after McCune and Mefford (2010). As far as the taxonomical identification of the weeds of the three crops is concerned, the weeds were identified with available literature after Nasir \& Ali (1970-1989), Ali \& Nasir (1990-1992) and Ali \& Qaisar (19922007).

\section{Results and Discussion}

A total of forty one (41) weed plant species belonged to twenty one (21) different families were recorded from chickpea, mustard and wheat crop fields of Tehsil Isa Khel, District Mianwali, Punjab. Twenty four (24) weed species were collected from chickpea, twenty five (25) from mustard and twenty nine (29) from wheat crop fields. While, among these forty one weed species, sixteen (16) weed species were found common in all these three crop fields which is $39.02 \%$, five (05) weed species were found in two crops which is $12.19 \%$ of the total weeds and twenty (20) weed species were found only in one crop which is $48.78 \%$ of the total weed distribution (Table 1). Among reported plant families in this study were Euphorbiaceae, Rubiacaeae, Apiaceae, Fabaceae, Ranunculaceae, Polygonaceae, Cyperaceae, Amaranthaceae, Chenopodiaceae,

Brassicaceae, Papaveraceae, Zygophyllaceae, Primulaceae, Apocynaceae, Cucurbitaceae, Boraginaceae, Asphodelaceae, Convolvulaceae which Convolvulaceae which was also reported by Sher et al. (2011) and Inayat et al. (2014) which indicates the prevalence and diversity of the weeds of these plant families in crop fields. Moreover, ecological communities of Chickpea, Mustard and Wheat crop of Tehsil Isa Khel (Mianwali) are divided into two major groups i.e. GA and GB. Group-A (GA) is further divided into two groups i.e. Group1 (GA1) and Group-2 (GA2).

\section{Group A:}

Group $A$ is further divided into two subgroups (SGs) i.e. SG1 and SG2. The Sub Group 1 (SG1) is represented by two associations i.e. Association 1 (A1) and Association 2 (A2). A1 consists of one weed specie i.e. Asphodelus tenuifolius along IVI of 41.30. Sub Group 2 (SG2) is further divided into two associations, A1 and $A 2 . A 1$ is divided into two Sub Associations i.e. sub association 1 (SA1) and sub association 2 (SA2) as shown in Figure 1. SA1 consists of two weed species as Medicago monantha and Setaria verticillata with IVI of 17.35 and 4.05 , respectively. SA2 consists of seven weeds i.e. Fagonia indica, Cynodon dactylon, Carthamus oxyacantha, Euphorbia dendroides, Convolvulus arvensis, Phalaris minor and Hordeum vulgare having IVI as 5.97, 7.93, 9.48, $5.72,3.93,7.52$ and 1.43 , respectively as shown in Table 1 . Presence of three grass members of the family Poaceae with such high IVI values in this association confirms the findings of Hussain et al. (2015). A2 has single sub association and consists of only one plant i.e. Daucus carota having IVI of 0.17 .

\section{Group B:}

Group B is further divided into two subgroups (SGs) i.e. SG1 and SG2. Sub Group 1 (SG1) is represented by two associations i.e. Association 1 (A1) and Association 2 (A2). Association 1 (A1) is further splits into two Sub Associations i.e. sub association 1 (SA1) and sub association 2 (SA2) as shown in Figure 1. Sub association 1 (SA1) consists of twenty weed species as Setaria pumila, Cucumis melo, Euphorbia helioscopia, Ranunculus muricatus, Euphorbia granulata, Launaea procumbens, Fumaria indica, Cyperus rotundus, Lathyrus aphaca, Hypochaeris radicata, Chenopodium album, Avena sativa, Hypecoum pendulum, Galium aparine, Artemisia sp., Launaea nudicaulis, Digera muricata, Rumex dentatus, Anchusa crispa and Oenothera biennis having IVI of $0.05,0.05,0.15$, $0.08,0.23,1.70,0.11,1.69,0.54,0.67$, $1.12,10.44,0.06,0.26,0.54,0.22,1.11$, $1.42,0.74$ and 0.91 , respectively as shown in Table 1. Sub Association 2 (SA2) consisted of only one weed i.e. Brassica campestris with IVI of 0.67. A2 (Association 2) is further divided into two sub associations i.e. sub association 1 (SA1) and sub association 2 (SA2). Sub association 1 (SA1) consists of four weed plant species i.e. Anagalis arvensis, 
Sonchus asper, Melilotus indicus and Tribulus terrestris having IVI i.e. 12.95, $0.58,1.12$ and 0.36 , respectively. Sub Association 2 (SA2) consists of three weeds as Chenopodium murale, Medicago polymorpha and Asclepias asperula having IVI values as $0.44,1.07$ and 0.75 , respectively. Sub Group 2 (SG2) is represented by single association consisting two plant species i.e. Chrozophora tinctoria and Setaria glauca having IVI i.e. 0.37 and 1.99 , respectively as shown in Figure 1 and Table 1.

Above mentioned groups and sub groups of the weed communities of three crop fields, sixteen (16) weed species i.e. Daucus carota, Asclepias asperula, Asphodelus tenuifolius, Carthamus oxyacantha, Anchusa crispa, Chenopodium album, Chenopodium murale, Convolvulus arvensis, Cyperus rotundus, Chrozophora tinctoria, Euphorbia dendroides, Medicago monantha, Fumaria indica, Cynodon dactylon, Hordeum vulgare and Fagonia indica were found common in all the three crops. Most of the weed plants like Cynodon dactylon, Rumex dentatus, Chenopodium album, Ranunculus muricatus, Medicago polymorpha, Tribulus terrestris, Anagallis arvensis, Cyperus rotundus, Melilotus indicus, Convolvulus arvensis and many other species are habitually known weeds of wheat fields from the other parts of country (Hussain et al., 2004; Mohammad et al., 2005; Akhtar and Hussain, 2007). During the survey Hypochaeris radicata, Oenothera biennis, Hypecoum pendulum, Launaea nudicaulis and Galium aparine were found only in chickpea crop. Digera muricata, Euphorbia granulata, Setaria pumila and Cucumis melo were present only in mustard crop while Phalaris minor, Setaria verticillata, Melilotus indicus, Sonchus asper, Avena sativa, Euphorbia helioscopia, Medicago polymorpha, Ranunculus muricatus, Lathyrus aphaca, and Artimisia species are found in the wheat field, followed the results of Nasir and Sultan (2002). Apart from other weed species Asphodelus tenuifolius, Carthamus oxyacantha and Convolvulus arvensis found in all the three crops with high relative frequency, with same life span. In different areas of Pakistan these wideranging weeds were reported (Qureshi \& Bhatti, 2001; Qureshi \& Arain, 2003; Jakhar et al., 2005). Although the weeds have negative impact on crops but there are certain weed species that are ethnomedicinally or ethnobotanically used such as Carthamus oxyacantha, Sonchus asper, Convolvulus arvensis, Cyperus rotundus, Chenopodium album and Cynodon dactylon confirm the previous studies (Ahmad et al., 2006; Shah and Khan, 2006). So, from the above discussion it can be concluded that weeds do behave noxiously to deteriorate the production rate of the crops but if the better management can be applied to conserve the ethnobotanical and ethnomedicinal weeds which could be helpful to conserve the local plant biodiversity.

Table 1: Phytosociological analysis of weeds of Chickpea, Mustard and Wheat crop fields of Tehsil Isa Khel (Mianwali), Punjab (Pakistan|)

\begin{tabular}{|c|c|c|c|c|c|c|c|c|c|}
\hline $\begin{array}{l}\text { Sr. } \\
\text { No. }\end{array}$ & Family & weed species & $* \mathrm{C} 1$ & $* \mathrm{C2}$ & $* \mathbf{C} 3$ & $* \mathbf{R F}$ & $* \mathbf{R C}$ & * RD & $*$ IVI \\
\hline 1 & Amaranthaceae & $\begin{array}{l}\text { 1. Digera muricata } \\
\text { (L.) Mart. }\end{array}$ & $x$ & $\sqrt{ }$ & $x$ & 2.51 & 0.56 & 0.3 & $1.11 \pm 0.69$ \\
\hline 2 & Apiaceae & 1. Daucus carota L. & $\sqrt{ }$ & $\sqrt{ }$ & $\sqrt{ }$ & 0.11 & 0.23 & 0.2 & $0.17 \pm 0.03$ \\
\hline 3 & Apocynaceae & $\begin{array}{l}\text { 1. Asclepias } \\
\text { asperula (Decne.) } \\
\text { Woodson }\end{array}$ & $\sqrt{ }$ & $\sqrt{ }$ & $\sqrt{ }$ & 1.64 & 0.41 & 0.2 & $0.75 \pm 0.44$ \\
\hline 4 & Asphodelaceae & $\begin{array}{l}\text { 1. Asphodelus } \\
\text { tenuifolius Cav. }\end{array}$ & $\sqrt{ }$ & $\sqrt{ }$ & $\sqrt{ }$ & 12.8 & 21.4 & 90 & $41.30 \pm 24.42$ \\
\hline \multirow[t]{3}{*}{5} & \multirow[t]{3}{*}{ Asteraceae } & 1. Artemisia sp. L. & $x$ & $x$ & $\sqrt{ }$ & 1.26 & 0.17 & 0.2 & $0.54 \pm 0.35$ \\
\hline & & $\begin{array}{l}\text { 2. Carthamus } \\
\text { oxyacantha M.Bieb. }\end{array}$ & $\sqrt{ }$ & $\sqrt{ }$ & $\sqrt{ }$ & 10.8 & 11.6 & 6 & $9.48 \pm 1.7$ \\
\hline & & 3. Hypochaeris & $\sqrt{ }$ & $x$ & $x$ & 0.54 & 0.28 & 1.2 & $0.67 \pm 0.27$ \\
\hline
\end{tabular}




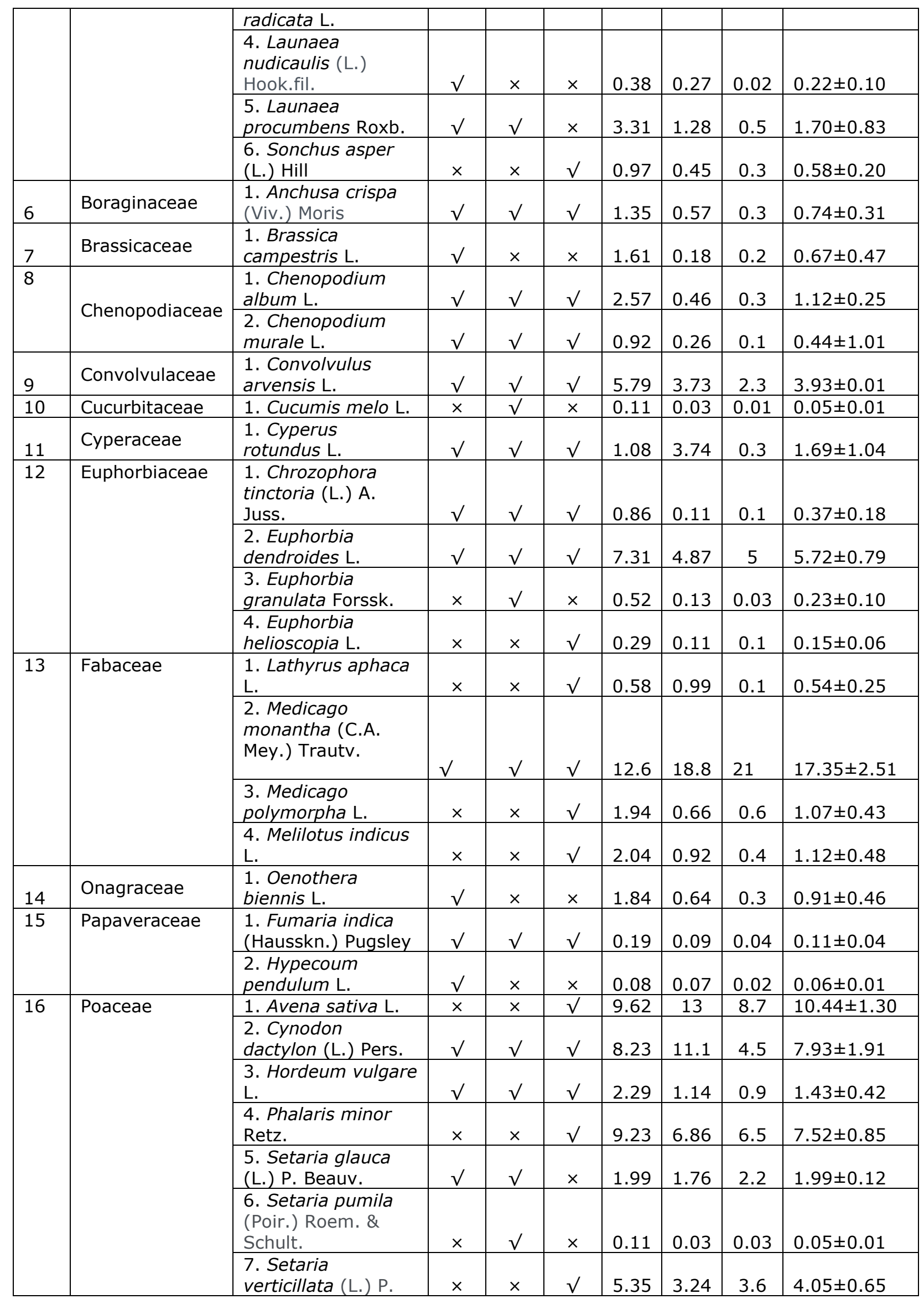




\begin{tabular}{|l|l|l|c|c|c|c|c|c|c|}
\hline & & Beauv. & & & & & & & \\
\hline 17 & Polygonaceae & $\begin{array}{l}1 . \text { Rumex dentatus } \\
\text { L. }\end{array}$ & $\times$ & $\sqrt{ }$ & $\sqrt{ }$ & 2.01 & 1.05 & 1.2 & $1.42 \pm 0.29$ \\
\hline 18 & Primulaceae & $\begin{array}{l}1 . \\
\text { arvensis L. Anagallis }\end{array}$ & $\times$ & $\sqrt{ }$ & $\sqrt{ }$ & 7.24 & 9.71 & 22 & $12.95 \pm 4.56$ \\
\hline 19 & Ranunculaceae & $\begin{array}{l}1 . \text { Ranunculus } \\
\text { muricatus L. }\end{array}$ & $\times$ & $\times$ & $\sqrt{ }$ & 0.19 & 0.03 & 0.02 & $0.08 \pm 0.02$ \\
\hline 20 & Rubiaceae & $\begin{array}{l}1 . \text { Galium aparine } \\
\text { L. }\end{array}$ & $\sqrt{ }$ & $\times$ & $\times$ & 0.61 & 0.11 & 0.1 & $0.26 \pm 1.68$ \\
\hline 21 & Zygophyllaceae & $\begin{array}{l}1 . \text { Fagonia indica } \\
\text { Burm. f. }\end{array}$ & $\sqrt{ }$ & $\sqrt{ }$ & $\sqrt{ }$ & 7.37 & 5.88 & 4.7 & $5.97 \pm 0.77$ \\
\hline & $\begin{array}{l}\text { 2. Tribulus } \\
\text { terrestris L. }\end{array}$ & $\times$ & $\sqrt{ }$ & $\sqrt{ }$ & 0.59 & 0.27 & 0.2 & $0.36 \pm 0.12$ \\
\hline
\end{tabular}

Key(s): Chickpea crop (*C1); Mustard crop (*C2); Wheat crop (*C3); Presence of weeds $(\sqrt{ })$; Absence of weeds $(\times)$; Relative Frequency (*RF); Relative Density (*RD); Relative Cover (*RC); Importance Value Index (IVI); Standard Error ( \pm ) 


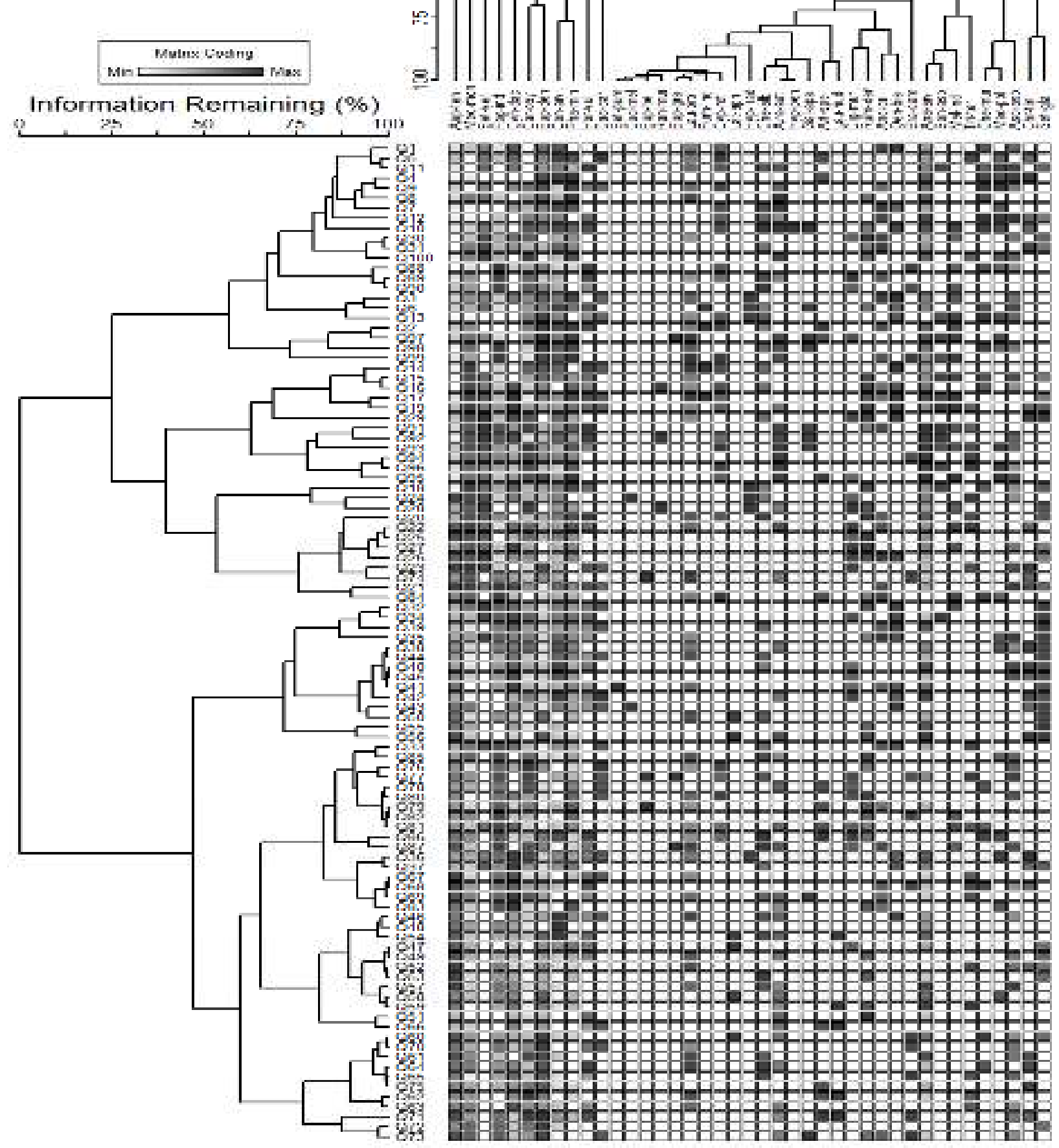

Fig. 1: Ecological grouping of weeds of chickpea, mustard and wheat crop fields of Tehsil Isa Khel (District Mianwali) Punjab 


\section{References}

Ahmad, M., M. A. Khan, M. Zafar and S. Sultana. 2006. Ethnomedicinal demography and ecological diversification of some important weeds from District Attock, Pakistan. Pak. J. Weed Sci. Res., 12(1-2): 3746.

Akhtar, N. and F. Hussain. 2007. Weeds of wheat fields of Qambar, District Swat, Pakistan. Pak. J. Pl. Sci., 13(1): 33-37.

Ali, S.I. and Y. Nasir. 1990-1992. Flora of Pakistan. No.191-193. University of Karachi.

Ali, S.I. and M. Qaiser. 1992-2007. Flora of Pakistan. Nos. 194-208. Department of Botany, University of Karachi and National Herbarium, PARC, Islamabad.

Anderson, C., H. Stryhn and J.C. Streibig. 1996. Decline of the flora in Danish arable fields. Journal of Applied Ecology, 33 (3):619-626.

Clements, F.E. 1906. Research Methods in Ecology. The University Publishing Company, Lincoln, Nebraska, USA.

Curtis, J.T. and R.P. McIntosh. 1950. The interrelation of certain analytic and synthetic phytosociological characters. Ecology, 31:434-455.

Daubenmire, R. 1959. A canopy coverage method of vegetational analysis. Northwest Science, 33: 43-64.

Fazal, Z., J. Gul, M. Subhan, K. Sher and Q. Ali. 2019. Floristic diversity and weed communities of maize, potato and mungbean crop of Kalash Valley Chitral, Hindukush range Khyber Pakhtunkhwa, Pakistan. Pak. J. Weed Sci. Res., 25(2): 79-90.

Hussain, F., A. Murad and M. J. Durrani. 2004. Weed communities in the wheat fields of Mastuj, District Chitral, Pakistan. Pak. J. Weed Sci. Res., 10(34):101-108.

Hussain, F., S. Aziz, G. Hassan, K. Aziz and S. Raisham. 2020. The first ever floristic and phytosociological studies on Cannabis sativa L. in the fields of Tirah-Maidan District Khyber, Pakistan. Pak. J. Weed Sci. Res., 26(2):195213.

Hussain, R., S. M. Wazir and R. Ullah. 2015. Floral diversity in gram fields of Tehsil Serai Naurang, District Lakki
Marwat, Pakistan. Pak. J. Weed Sci. Res., 22(1): 111-124.

Inayat, N., A. Ullah and A. Rashid. 2014. Floristic composition and ecological prevalence

the weed species growing in wheat and sugar cane fields of district Charsadda, Khyber Pakhtunkhwa, Pakistan. Pak. J. Weed Sci. Res., 20(3): 405-415.

Iqbal, M., S. M. Khan, M. A. Khan, Z. Ahmad, Z. Abbas, S.M. Khan and M. S. Khan. 2017. Distribution pattern and species richness of natural weeds of wheat in varying habitat conditions of District Malakand, Pakistan. Pak. J. Bot., 49(6): 2371-2382.

Jakhar, G. S., A. Q. Mahar, S.A. Abro and R. Qureshi. 2005. Weed communities of wheat crop under diverse Edaphography of District Khairpur. Pak. J. Bot., 37(3):709-714.

Marwat, S. K., K. Usman, N. Khan, M.U. Khan, E.A. Khan, M. A. Khan and A. Rehman. 2013. Weeds of wheat crop and their control strategies in Dera Ismail Khan District, Khyber Pakhtun Khwa, Pakistan. Am. J. Plant Sci., 4: 66-76.

McCune, B. and M.J. Mefford. 2010. PCORD: Multivariate Analysis of Ecological Data. Version 6.21. MjM Software Design, Gleneden Beach, Oregon, USA.

McIntosh, R.P. 1962. Raunkiaer's Law of frequency. Ecology, 43(3): 533-535.

Mohammad, S., T. A. Cheema, Z. Bashir and R. Mehmood. 2005. Analytical characteristics of weeds of wheat crop of Tehsil Gojra, Toba Tek Singh, Pakistan. Pak. J. Pl. Sci., 11(1):57-60.

Nagaraju, N., B.V. Rao and M.T. Naidu. 2014. Phytosociological studies on weed species of sugarcane fields in Visakhapatnam District, Andhra Pradesh, India. Int. J. Adv. Res. Sci. Technol., 3: 23-28.

Nasir, E. and S.I. Ali. 1970-89. Flora of Pakistan. Nos. 1-190. National Herbarium, PARC, Islamabad and Department of Botany, University of Karachi, Pakistan.

Nasir, Z. A. and S. Sultan. 2002. Floristic biological and leaf size spectra of 
weeds in gram, lentil, mustard and wheat fields of District Chakwal, Pakistan. Pak. J. Bio. Sci., 5(7):758762.

Navagana, N., V.R. Bandaru and N.M. Tarakeswara. 2017. Phytosociological studies on the weed flora of cotton crop in Visakhapatnam District, Andhra Pradesh, India. Int. J. Curr. Res., 9(1):44583-44587.

Padal, S. B., S. Sandhya, R.J. Buchi and K.B. Rama. 2013. Floristic diversity and indigenous uses of dominated weeds in maize crop of Chinthapalli mandal, Visakhapatnum District, Andhra Pradesh, India. J. Agric. Vet. Sci., 2(6):56-63.

Qureshi, R. and G. R. Bhatti. 2001. Determination of weed communities in wheat (Triticum aestivum L.) fields of district Sukkur, Pakistan. Pak. J. Bot., 33(1): 109-115.

Qureshi, R. and M. A. Arian. 2003. Spectrum, density and frequency of weeds of wheat crop in Sukkur District, Sindh, Pakistan. Hamdard Medicus, 34-38.

Risser, P.G. and E.L. Rice. 1971. Phytosociological analysis of Oklahoma upland forest species. Ecology, 49: 1006-1009.

Samreen, U., M. Ibrar, L. Badshah and M. Imran. 2018. Diversity and ecological characteristics of weed flora at Darazinda, Frontier Region, Dera Ismail Kahn, Pakistan. Pak. J. Weed Sci. Res., 24(3): 223-229.

Shah, G. M. and M. A. Khan. 2006. Checklist of noxious weeds of district Mansehra Pakistan. Pak .J. Weed Sci. Res., 12(3): 213-219.

Sher, Z., F. Hussain, L. Badshah and M. Wahab. 2011. Floristic composition, communities and ecological characteristics of weeds of wheat fields of Lahor, District Swabi, Pakistan. Pak. J. Bot., 43(6): 2817-2820.

Ullah, F., A. Ullah, A. Sohail and R. Khan. 2015. Distribution and ecological importance of weeds in the maize crop at Maidan Valley, Dir (L), Khyber Pakhtun Khwa, Pakistan. Pak. J. Weed Sci. Res., 21(4): 543-553.

Waheed, A., R. Qureshi, G.S. Jakhar and H. Tareen. 2009. Weed community dynamics of District Rahim Yar Khan, Pakistan. Pak. J. Bot., 41(1): 247-254. Zeb, U., H. Khan, B. Gul and W.M. Khan. 2016. Floristic composition and phytosociological studies of Hazar Nao hills district Malakand, Khyber Pakhtunkhwa, Pakistan. Pak. J. Weed Sci. Res., 22(2): 295-315. 